\title{
Prevalence and Risk Factors Associated with Bacterial Vaginosis and Candidiasis in Non-Pregnant Women of Western Odisha, India
}

\author{
Madhumita Nayak ${ }^{1}$, Shalini Sinha², Alliyatri Debta ${ }^{3}$, Prasanta Purohit ${ }^{4}$, \\ Siris Patel ${ }^{5}$, Ojaswini Patel ${ }^{6}$, Padmalaya Das ${ }^{7}$, Sunanda Sahoo ${ }^{8}$
}

\begin{abstract}
${ }^{1}$ School of Life Sciences, Sambalpur University, Jyoti Vihar, Burla, Odisha, India. ${ }^{2}$ School of Life Sciences, Asian Institute of Public Health, Bhubaneswar, Odisha, India. ${ }^{3}$ School of Life Sciences, Asian Institute of Public Health, Bhubaneswar, Odisha, India. ${ }^{4}$ Multi-Disciplinary Research Unit, M.K.C.G. Medical College, Berhampur, Odisha, India.

${ }^{5}$ Veer Surendra Sai Institute of Medical Sciences \& Research, Burla, Odisha, India. ${ }^{6}$ Department of Obstetrics \& Gynecology, Veer Surendra Sai Institute of Medical Sciences \& Research, Burla, Odisha, India. ${ }^{7}$ School of Life Sciences, Asian Institute of Public Health, Bhubaneswar, Odisha, India.

${ }^{8}$ School of Life Sciences, Sambalpur University, Jyoti Vihar, Burla, Odisha, India.
\end{abstract}

\section{ABSTRACT}

\section{BACKGROUND}

The prevalence of Bacterial Vaginosis (BV) and candidiasis is high in Indian women in the reproductive age groups. Poor menstrual hygiene management (MHM) practices and low socio-demographic features are the major risk factors associated with BV and candidiasis. The aim of the study was to access the MHM practices in association with BV and Candida infection in the population of western Odisha.

\section{METHODS}

This cross-sectional study was carried out in the outpatient department of 0 \& G, VIMSAR, Burla, Odisha, from December 2016 to November 2018. Vaginal swabs were collected from the posterior vaginal fornix for analysis. BV was diagnosed by using Nugent's laboratory diagnostic criteria and identification of Candida was done by Albi Quick ${ }^{\mathrm{TM}}$ rapid test. A pre-coded questionnaire was used to collect demographic, clinical, and behavioural (MHM practices) features from the study participants. All data were double-entered into Epi Info 7 software and analysed using Stata 11.0.

\section{RESULTS}

In 352 women, the prevalence of $\mathrm{BV}$ and candidiasis was found in $38.92 \%$ $(137 / 352)$ and $32.67 \%(115 / 352)$ of women respectively. Women were divided into three groups on the basis of age i.e. 18-25 years: 87 (24.72\%); 26-35 years: 194 (55.11\%); and 36-45 years: 71 (20.17\%). Both BV and candidiasis were significantly high in women of 36-45 years age group compared to 18-25 years age group $(\mathrm{p}<0.05)$. Women of $36-45$ years age group had more number of cases with low education (19.72\%), housewife (67.61\%), and living in rural villages $(61.97 \%)$ compared to younger women $(\mathrm{p}<0.05)$. Regarding MHM practices, women in the higher age groups used more reusable cloths as absorbent materials $(p<0.002)$, changed absorbent material less frequently $(p=0.042)$ and changed their absorbents somewhere other than in a toilet facility $(\mathrm{p}<0.018)$ compared to younger women.

\section{CONCLUSIONS}

The higher prevalence of BV and candidiasis in higher age groups of women may be due to the poor MHM practices, lack of higher education and other low sociodemographic conditions compared to younger age women. An increased awareness for MHM practices is important to combat the associated morbidities related to BV and candidiasis.

\section{KEY WORDS}

Bacterial Vaginosis, Candidiasis, Menstrual Hygiene Management Practices, Age, Odisha

\author{
Corresponding Author: \\ Dr. Sunanda Sahoo, \\ School of Life Sciences, \\ Sambalpur University, Jyoti Vihar, \\ Burla, Odisha, India. \\ E-mail: drsunanda_sahoo@yahoo.com
}

DOI: $10.14260 /$ jemds $/ 2020 / 190$

Financial or Other Competing Interests None.

How to Cite This Article:

Nayak M, Sinha $S$, Debta $A$, et al Prevalence and risk factors associated with bacterial vaginosis and candidiasis in nonpregnant women of Western Odisha, India. J. Evolution Med. Dent. Sci. 2020;9(11): 884-890, DOI: 10.14260/jemds/2020/190

Submission 25-01-2020,

Peer Review 23-02-2020,

Acceptance 26-02-2020,

Published 16-03-2020.

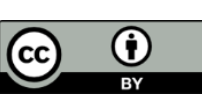




\section{BACKGROUND}

Bacterial vaginosis (BV) and vulvovaginal candidiasis are the major urinary tract infections in women worldwide. According to the Centers for Disease Control and Prevention, $\mathrm{BV}$ is the most common vaginal infection in women in the reproductive age (15-44 years of age). ${ }^{1} \mathrm{BV}$ is a condition characterized by shifting of vaginal microbial flora from a predominant population of lactobacilli to anaerobic microorganisms such as Gardnerella vaginalis, Prevotella, Bacteroides and Mobiluncus species, and with other bacteria including Mycoplasma and Ureaplasma species. ${ }^{2}$ Women with BV usually have a dense biofilm which consisting of a matrix of polysaccharides, proteins, extracellular DNA and embedded bacteria that tightly attached to the surface of vaginal epithelial cells. Gardnerella vaginalis alone represents around $80 \%$ of the total microbial species present in the biofilm. ${ }^{3-4}$ Women with BV usually have various symptoms of mucosal inflammation including, abnormal vaginal discharge, itching and burning, redness and swelling, dysuria, dyspareunia, pain etc. ${ }^{5}$ The characterization of BV can be done by various aspects such as epidemiological, microscopic, bacterial culture, molecular diagnosis methods. However all these methods have failed to reveal a common aetiology which can be consistently documented in all women with BV. ${ }^{5}$ Candidiasis is an infection caused by Candida species such as Candida albicans that affects millions of women every year.6-7 The signs and symptoms for candidiasis is thick and white vaginal discharge, redness and swelling of vaginal opening, pain, soreness and itching of vulva etc.

Globally, the prevalence of BV ranges from 8 to $51 \%$ and found to be varied with geographical location, socioeconomic status and ethnicity of the women. ${ }^{8}$ Similarly, around $75 \%$ of women may experience candidiasis during their lifetimes world-wide. ${ }^{9}$ Many factors have been found to be associated with occurrence of $\mathrm{BV}$ and/or candidiasis including socio-demographic features such as age of the women, socio-economic status, residency and education, sexual relationship, douching, menstrual hygiene practices and, water accessibility and sanitation etc. Younger women in the reproductive age have been found to be associated with $\mathrm{BV}$ in a number of studies. In contrast, women also experienced with a high BV in their $4^{\text {th }}$ and $5^{\text {th }}$ decades of life. ${ }^{10-12}$ In India, there are only few studies on the causes of $\mathrm{BV}$ and Candida infection in the women of reproductive age including the state of Odisha. ${ }^{13-18}$ Most of these studies have found a poor menstrual hygiene practices with low education and low socio-economic status behind both BV and Candida infection.

The poor menstrual hygiene practices include use of reuse clothes for absorbent materials instead of sanitary pads, frequency of changing of absorbent materials, change of absorbent materials outside the toilet facilities, washing and storage of reusable absorbent materials, wash variables etc. Further, there is a paucity of literatures on the prevalence of BV and Candida infection in the population with predominates of tribal communities. Studies on tribal population are important because of their traditional menstrual hygiene practices and socio-demographic determinants. This study was undertaken with an aim to access the menstrual hygiene management practices in association with BV and Candida infection in the population of western Odisha.

\section{METHODS}

This was a cross-sectional study that surveyed women attending to the out-patient department (OPD) of Department of Obstetrics and Gynaecology (O\&G) of Veer Surendra Sai Institute of Medical Sciences and Research (VIMSAR), Burla, Odisha, India. It is a tertiary care referral hospital for 12 million people residing in western Odisha and the state of Chhattisgarh. The hospital caters to both urban as well as rural area. In this institution, almost all the health care services are provided free of cost, hence the majority of the study participants attending this hospital were from the financially disadvantaged groups. The patient recruitment was done from December 2016 to November 2018. The study was approved by Institutional Ethical Committee of Veer Surendra Sai Institute of Medical Sciences and Research (VIMSAR), Burla, Odisha (IEC/IRB-14/16).

\section{Study Population}

Non-pregnant women of reproductive age between 18-45 years, attending the $0 \& G$ outpatient department with vaginal symptoms such as abnormal vaginal discharge, itching, burning, dyspareunia, with lower abdominal pain, lower back pain were eligible for enrolment into the study. We excluded women who: were pregnant, menopausal women, were already undergoing treatment, were menstruating during the clinic visit, had had a hysterectomy, had taken a course of antibiotics during the previous three weeks, had used oral contraceptive pills in the previous three months, had diabetes mellitus, were HIV positive, or had any severe medical disorders requiring immediate referral to a higher level of health care. Considering the average prevalence of BV and candidiasis of 35\% in Indian population with $95 \%$ confidence level and 5\% error, the sample size was calculated as 350 .

\section{Data Collection}

After identification by the treating doctor, all potential study participants underwent an informed consent process in local language and provided written consent if they wanted to participate in the study. The participants were informed that they would be tested for reproductive tract infection. A predesigned questionnaire was asked to each woman. The questionnaire contains the information on sociodemographic factors (include age, marital status, religion, education, occupation, number of family member and monthly income), MHM practices and water and sanitation conditions in their household and clinical manifestations. Information on MHM practices included the type of menstrual absorbent used and individual hygiene habits. Questions on the use of absorbents materials included: the type of absorbent (reusable/disposable), the type of material used in reusable absorbents, frequency and place of change absorbent. In the case of reusable absorbents, information on the method of washing, drying, packaging, and storing were also asked. Information on water and sanitation conditions in their households, include information about access to latrine 
Number of women visited O \& G-OPD at VIMSAR, Burla, Odisha, India during the study period $(\mathrm{N}=1014)$
Excluded from the study:

- Diabetes, HIV infection, antibiotic use: 98

- Pregnant women: 281

- Menopausal women: 209

Refused consent: 74

Figure 1. Schematic Diagram of Recruitment of Participants at VIMSAR, Burla, Odisha, India

and place where the main water source is located. Clinical symptoms related to vaginal discharge included its quantity, smell, colour, and consistency, burning or itching of the genitalia, and the presence of ulcers at vulva and labia, vesicles, papules.

\section{Collection of Vaginal Samples}

A speculum examination of vagina and cervix was done by a trained 0 \& G specialist, particularly to look for the presence of cervical erythema, bleeding, inflammation, with or without discharge, and ulcers at cervix. Vaginal specimens from posterior vaginal fornix were collected using two BD BBL swabs (BD, Maryland, USA). The first swab was used for Gram staining to diagnose $\mathrm{BV}$ and the second swab was used to determine the presence of Candida. After labelling, all materials (slides and swabs) were preserved in the laboratory for subsequent diagnosis.

\section{Diagnosis of BV and Candida Infection}

BV was diagnosed using Nugent's laboratory diagnostic criteria. ${ }^{19}$ In brief, slides prepared from the vaginal swabs were stained with Gram's stain and examined for specific bacterial morphotypes. ${ }^{19}$ A Nugent score (NS) between 0-10 was generated using the Nugent criteria. A NS of 0 to 3 was interpreted as normal or negative for BV, a score of 4 to 10 as intermediate/abnormal for BV or positive for BV. Albi Quick $^{\mathrm{TM}}$ rapid test (HARDY Diagnostic, CA, USA) was used for identification of Candida albicans as per manufacturer's instructions. Briefly, the vaginal swab was cultured in Blood Agar and Chocolate Agar plate for $48 \mathrm{hr}$ at $37^{\circ} \mathrm{C}$. After $48 \mathrm{hr}$, a sample was taken in a sterile loop and smeared on the test card for 5 min at room temperature. A bright blue-white or blue-purple fluorescence was observed for positive Candida albicans infection and no fluorescence was seen for negative samples. During the study period, 1014 women who visited the gynaecology OPD of the hospitals, 352 reproductive age women were enrolled in the study, 74 did not consent to participate and a further 588 were excluded according to our criteria (figure 1).

\section{Statistical Analysis}

Generated data was entered into Epi Info 7 software. Data were presented in number followed by percentage. Chi square test was performed for comparison of categorical data among the groups, A p value of $<0.05$ was considered for statistically significant. All the statistical analysis was performed by using Stata 11.0 (StataCorp, Stata Statistical Software: Release 11. 2011, StataCorp LP: College Station, TX).

\section{RESULTS}

All the 352 women were categorised into 3 age groups i.e. 1825 years, $26-35$ years and $36-45$ years. There were $24.72 \%$ $(n=87), 55.11 \%(n=194)$ and $20.17 \%(n=71)$ non-pregnant women present in each age group. All women were married in each age group except $19.54 \%$ single women were there in the age group 18-25 years ( $\mathrm{p}<0.001)$. Though most women belong to Hindu religion but no statistical difference was found $(\mathrm{p}<0.362)$. Majority of women had attained $12^{\text {th }}$ grade or higher education and the difference was statistically significant $(\mathrm{p}<0.002)$. While monthly income didn't show any statistical significance $(\mathrm{p}<0.052)$, the primary occupation of the participants was housewife and showed statistical significance $(p<0.039)$ between three different age groups, 
however $16.49 \%$ women in 26-35 age group were employed compared to $8.05 \%$ in $18-25$ age group and $4.23 \%$ in $36-45$ age group. More than $60 \%$ women living in rural areas belong to $26-35$ age group and $36-45$ age group compared to $47.13 \%$ in 18-25 age group and showed statistical significance $(\mathrm{p}<0.030)$ (table 1).

Abnormal vaginal discharge was reported in $67.01 \%$ women in the $26-35$ years age group followed by $60.56 \%$ in $36-45$ years age group and $42.53 \%$ in $18-25$ years age group. A significant difference was also found $(\mathrm{p}<0.001)$. Feeling of burning or itching in genitalia, another symptom which was reported frequently by $69 \%$ in 36-45 years age group women compared to $62.89 \%$ women in $26-35$ age group and $47.13 \%$ in 18-25 years age group women and showed statistically significant $(\mathrm{p}<0.011)$. Among all age groups, women in the 26-35 years age group used more contraceptive (58.25\%) compared to other two age groups $(\mathrm{p}<0.001)$. BV was diagnosed using Nugent's diagnostic criteria. There were 215 $(61.07 \%)$ women with normal Nugent score (NS 0-3), 84 $(23.86 \%)$ with intermediate Nugent score (NS 4-6), and 53 (15.05\%) with BV (NS 7-10). This difference was found to be statistically significant (0.006) (table 2). Vaginal $\mathrm{pH}$ was $<4.5$ in 205 women, and $\mathrm{pH} \geq 4.5$ was found in 147 women and found to be statistically significant differences ( $p<0.040$ ) (table 2). Candida infection was observed in $22.99 \%, 34.02 \%$ and $40.85 \%$ of women in $18-25,26-35$ and $36-45$ age group respectively $(\mathrm{p}<0.049)$ with the overall prevalence of $32.67 \%$. Similarly, the prevalence of BV in 18-25, 26-35 and 36-45 age group was $28.74 \%, 40.21 \%$ and $47.89 \%$ respectively $(\mathrm{p}<0.042)$ with the overall prevalence of $38.92 \%$ (figure 2). Women in the 36-45 age group used reusable cloths more $(60.56 \%)$ compared to $51.55 \%$ in $26-35$ age group and $33.33 \%$ in $18-25$ age group women. However, women in 1825 age group used more disposable $(66.67 \%)$ compare to other two groups.

\begin{tabular}{|c|c|c|c|c|}
\hline Variables & $\begin{array}{c}\text { 18-25 Yrs. } \\
(\mathrm{N}=87)\end{array}$ & $\begin{array}{c}\text { Age }(\mathrm{N}=352) \\
26-35 \text { Yrs. } \\
(\mathrm{N}=194)\end{array}$ & $\begin{array}{c}\text { 36-45 Yrs. } \\
(\mathrm{N}=71)\end{array}$ & $\mathbf{p}$ \\
\hline Marital status & & & & \multirow{4}{*}{0.001} \\
\hline Single, never married & $17(19.54)$ & 0 & 0 & \\
\hline Married & $70(80.46)$ & 191(98.45) & $68(95.77)$ & \\
\hline Divorced/Widowed & 0 & $3(1.55)$ & $3(4.23)$ & \\
\hline \multicolumn{5}{|l|}{ Religion } \\
\hline Hindu & $83(95.40)$ & $175(90.21)$ & $68(95.77)$ & \multirow{3}{*}{0.362} \\
\hline Muslim & $2(2.30)$ & $14(7.22)$ & $2(2.82)$ & \\
\hline Christian & $2(2.30)$ & $5(2.58)$ & $1(1.41)$ & \\
\hline \multicolumn{5}{|l|}{ Caste/Tribe } \\
\hline Scheduled caste (SC) & $18(21.18)$ & $31(16.40)$ & $13(18.57)$ & \multirow{4}{*}{0.416} \\
\hline Scheduled tribe (ST) & $28(32.94)$ & $70(37.04)$ & $26(37.14)$ & \\
\hline Other backward caste OBC) & $23(27.06)$ & $68(35.98)$ & $20(28.57)$ & \\
\hline General & $16(18.82)$ & $20(10.58)$ & $11(15.71)$ & \\
\hline \multicolumn{5}{|l|}{ Education } \\
\hline No formal education & $10(11.49)$ & $27(13.92)$ & 14(19.72) & \multirow{3}{*}{0.002} \\
\hline 5 th -10 th grade & $30(34.48)$ & $108(55.67)$ & $35(49.30)$ & \\
\hline 12 th grade or higher & $47(54.02)$ & $59(30.41)$ & $22(30.99)$ & \\
\hline \multicolumn{5}{|l|}{ Occupation } \\
\hline Employed & $7(8.05)$ & $32(16.49)$ & $3(4.23)$ & \multirow{3}{*}{0.039} \\
\hline Self-employed & $22(25.29)$ & $54(27.84)$ & $20(28.17)$ & \\
\hline Housewife & $58(66.67)$ & $108(55.65)$ & $48(67.61)$ & \\
\hline \multicolumn{5}{|l|}{ Number of people live in } \\
\hline house & $19(21.84)$ & $19(9.79)$ & $7(9.86)$ & \multirow{3}{*}{0.052} \\
\hline $1-2$ individuals & $\begin{array}{l}19(21.84) \\
55(63.22)\end{array}$ & $149(76.80)$ & $52(73.24)$ & \\
\hline 3-5 individuals & $13(14.94)$ & $26(13.40)$ & $12(16.90)$ & \\
\hline \multicolumn{5}{|l|}{ Monthly Income } \\
\hline$<5,000$ & $9(10.34)$ & $32(16.49)$ & $10(14.08)$ & \multirow{3}{*}{0.346} \\
\hline $5,000-10,000$ & $45(51.72)$ & $87(44.85)$ & $27(38.03)$ & \\
\hline$>10,000$ & $33(37.93)$ & $75(38.66)$ & $34(47.89)$ & \\
\hline \multicolumn{5}{|l|}{ Where Live } \\
\hline Housing colony & $24(27.59)$ & $31(15.98)$ & $9(12.68)$ & \multirow{3}{*}{0.030} \\
\hline Urban slum & $22(25.29)$ & $37(19.07)$ & $18(25.35)$ & \\
\hline Rural/village & $41(47.13)$ & $126(64.95)$ & $44(61.97)$ & \\
\hline \multicolumn{5}{|c|}{$\begin{array}{l}\text { Table 1. Sociodemographic Status of Non-Pregnant } \\
\text { Women Recruited in the Study }\end{array}$} \\
\hline
\end{tabular}

\begin{tabular}{|c|c|c|c|c|}
\hline Variables & $\begin{array}{l}\text { 18-25 Yrs. } \\
(\mathrm{N}=87)\end{array}$ & $\begin{array}{l}\text { 26-35 Yrs. } \\
(\mathrm{N}=194)\end{array}$ & $\begin{array}{l}\text { 36-45 Yrs. } \\
(\mathrm{N}=71)\end{array}$ & $\mathbf{p}$ \\
\hline \multicolumn{5}{|c|}{ Abnormal vaginal discharge } \\
\hline No & $50(57.47)$ & $64(32.99)$ & $28(39.44)$ & \multirow[t]{2}{*}{0.001} \\
\hline Yes & $37(42.53)$ & $130(67.01)$ & $43(60.56)$ & \\
\hline \multicolumn{5}{|c|}{$\begin{array}{c}\text { Feeling of burning or itching in } \\
\text { genitalia }\end{array}$} \\
\hline No & $46(52.87)$ & $72(37.11)$ & $22(30.99)$ & \multirow[t]{2}{*}{0.011} \\
\hline Yes & $41(47.13)$ & $122(62.89)$ & $49(69.01)$ & \\
\hline \multicolumn{5}{|l|}{ Genital sores } \\
\hline No & $86(98.85)$ & 186(95.88) & $66(92.96)$ & \multirow[t]{2}{*}{0.167} \\
\hline Yes & $1(1.15)$ & $8(4.12)$ & $5(7.04)$ & \\
\hline \multicolumn{5}{|c|}{$\begin{array}{l}\text { Feeling of burning or itching when } \\
\text { urinating }\end{array}$} \\
\hline No & $52(59.77)$ & $112(57.73)$ & $39(54.93)$ & \multirow[t]{2}{*}{0.829} \\
\hline Yes & $35(40.23)$ & $82(42.27)$ & $32(45.07)$ & \\
\hline \multicolumn{5}{|c|}{ Strawberry cervix } \\
\hline No & $11(12.64)$ & $24(12.37)$ & $12(16.90)$ & \multirow[t]{2}{*}{0.615} \\
\hline Yes & $76(87.36)$ & $170(87.63)$ & $59(83.10)$ & \\
\hline \multicolumn{5}{|c|}{ Lower back pain } \\
\hline No & $47(54.02)$ & $119(61.34)$ & $43(60.56)$ & \multirow[t]{2}{*}{0.500} \\
\hline Yes & $40(45.98)$ & $75(38.66)$ & $28(39.44)$ & \\
\hline \multicolumn{5}{|c|}{ Use contraceptive } \\
\hline No & $60(73.17)$ & $81(41.75)$ & $45(63.38)$ & \multirow{2}{*}{0.001} \\
\hline Yes & $22(26.83)$ & $113(58.25)$ & $26(36.62)$ & \\
\hline \multicolumn{5}{|c|}{ Nugent scoring } \\
\hline $0-3$ & $62(71.26)$ & $116(59.79)$ & $37(52.11)$ & \multirow{3}{*}{0.006} \\
\hline $4-6$ & $22(25.29)$ & $41(21.13)$ & $21(29.58)$ & \\
\hline 7 or more & $3(3.45)$ & $37(19.07)$ & $13(18.31)$ & \\
\hline \multicolumn{5}{|l|}{ pH cat } \\
\hline$<4.5$ & $59(67.82)$ & $112(57.73)$ & $34(47.89)$ & \multirow{2}{*}{0.040} \\
\hline$\geq 4.5$ & $28(32.18)$ & $82(42.27)$ & $37(52.11)$ & \\
\hline \multicolumn{5}{|c|}{$\begin{array}{l}\text { Table 2. Clinical Presentation of Non-Pregnant } \\
\text { Women Recruited in the Study }\end{array}$} \\
\hline
\end{tabular}

\begin{tabular}{|c|c|c|c|c|}
\hline Variables & $\begin{array}{l}\text { 18-25 Yrs. } \\
(\mathrm{N}=87)\end{array}$ & $\begin{array}{l}\text { 26-35 Yrs. } \\
(\mathrm{N}=194)\end{array}$ & $\begin{array}{l}\text { 36-45 Yrs. } \\
(\mathrm{N}=71)\end{array}$ & p \\
\hline \multicolumn{5}{|c|}{$\begin{array}{l}\text { Absorbent material used during } \\
\text { last } 6 \text { cycles }\end{array}$} \\
\hline Disposable sanitary pads & $58(66.67)$ & $94(48.45)$ & $28(39.44)$ & 0.002 \\
\hline Reusable cloths/towel & $29(33.33)$ & $100(51.55)$ & $43(60.56)$ & \\
\hline \multicolumn{5}{|l|}{$\begin{array}{l}\text { Frequency of changing absorbent } \\
\text { material in heavy days }\end{array}$} \\
\hline Once a day & $39(44.83)$ & $85(43.81)$ & $44(61.97)$ & 0.042 \\
\hline Twice a day & $29(33.33)$ & $79(40.72)$ & $20(28.17)$ & \\
\hline Three times a day or more & $19(21$. & $30(15.46)$ & $7(9.86)$ & \\
\hline \multicolumn{5}{|l|}{ Where change absorbent material } \\
\hline Inside the toilet facility & $59(67.82)$ & $121(62.37)$ & $33(46.48)$ & 0.018 \\
\hline Outside the toilet facility & $28(32.18)$ & $73(37.63)$ & $38(53.52)$ & \\
\hline \multicolumn{5}{|l|}{ Dry sanitary cloth } \\
\hline Dry it in the sun or open s & $17(58.62)$ & $41(41.00)$ & $13(30.23)$ & 0.05 \\
\hline Dry it inside the house & 12( & 59( & 30( & \\
\hline \multicolumn{5}{|l|}{ How store cloth for next use } \\
\hline \multicolumn{4}{|l|}{ Wrapped in polythene/paper/ } & 0.81 \\
\hline Without wrapping & 3) & 40( & $16(3$ & \\
\hline \multicolumn{5}{|l|}{$\begin{array}{l}\text { Where store cloth for next use } \\
\text { In the cupboard/selves along with }\end{array}$} \\
\hline \multirow{2}{*}{$\begin{array}{l}\text { other clothes } \\
\text { In some place in the latrine or } \\
\text { bathroom }\end{array}$} & $24(82$ & $75(75.00)$ & $34(79$. & 0.647 \\
\hline & $5(17.24)$ & $25(25$ & $9(2$ & \\
\hline \multicolumn{5}{|l|}{$\begin{array}{l}\text { Type of washing during } \\
\text { Menstruation }\end{array}$} \\
\hline Only vaginal wash & $72(8$ & 139( & $45(6$ & 0.022 \\
\hline Bath of full body & $15(17.44)$ & $55(28.35)$ & $26(36.62)$ & \\
\hline \multicolumn{5}{|l|}{$\begin{array}{l}\text { How often wash yourself during } \\
\text { menstruation }\end{array}$} \\
\hline Once a day & $54(62.07)$ & $128(67.02)$ & $39(54.93)$ & 0.189 \\
\hline Twice or more per day & $33(37.93)$ & $63(32.98)$ & $32(45.07)$ & \\
\hline \multicolumn{5}{|l|}{ Household drinking water } \\
\hline Piped tap & $29(33.33)$ & $60(30.93)$ & $20(28.17)$ & \\
\hline Tube well/borehole/protected well & $43(49.43)$ & $91(46.91)$ & $33(46.48)$ & .79 \\
\hline Unprotected well & $15(17.24)$ & $43(22.16)$ & $18(25.35)$ & \\
\hline $\begin{array}{l}\text { Table 3. Different Menstru } \\
\text { WASH Access Variables of } \\
\text { Study according to their }\end{array}$ & $\begin{array}{l}\text { Lyiene } M \\
\text {-Pregnan } \\
\text { Categorie }\end{array}$ & $\begin{array}{l}\text { nagement } \\
\text { Women } R \\
\text { Data are } \\
\text { nen }\end{array}$ & $\begin{array}{l}\text { Practices } \\
\text { cruited in } \\
\text { xpressed }\end{array}$ & \\
\hline
\end{tabular}

The difference was found to be statistically significant $(\mathrm{p}<0.002)$.When we assessed the different MHM practices, women in 36-45 age group changed absorbent material less frequently $(61.97 \%)$ as compared to other two groups which were $43.81 \%$ and $44.83 \%$. Women changing their absorbents somewhere other than in a toilet facility found to be significantly different among all three age groups $(p<0.018)$. Women in 18-25 years age group washed themselves less 
frequently during menstruation (82.56\%) followed by $71.65 \%$ in $26-35$ years age group and $63.38 \%$ in $36-45$ age group. The difference was statistically significant $(\mathrm{p}<0.022)$ (table 3).

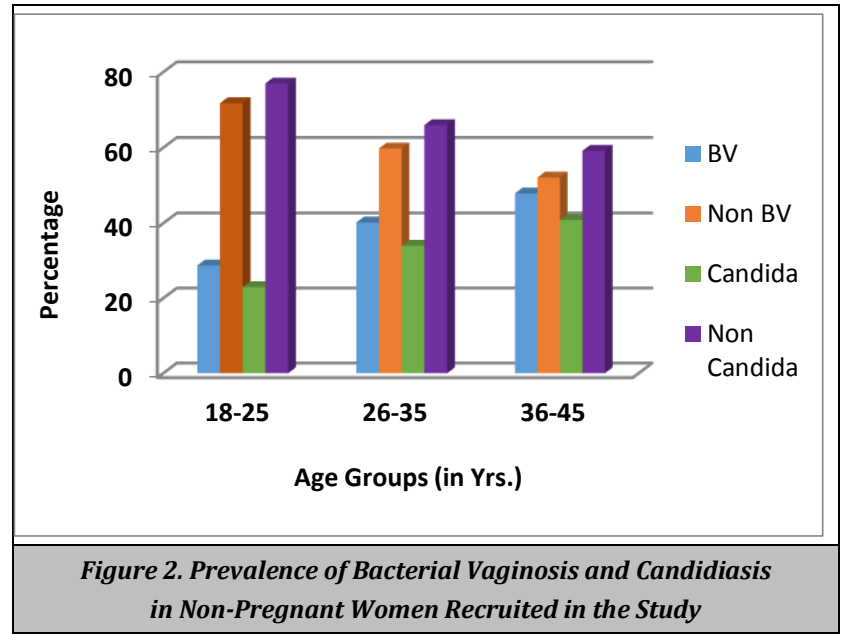

\section{DISCUSSION}

Three hundred and fifty-two women attending to the Obstetrics and Gynaecology outpatient department with the complaints of abnormal vaginal discharge, itching and burning of the genitalia, and other symptoms of the vaginitis were recruited in this study. Abnormal vaginal discharge and itching of genitalia was presented in around $60 \%$ of women although there was a significant difference observed across the ages of the women. Abnormal vaginal discharge and itching and burning has been found to be associated with occurrence of BV and candidiasis in many studies.20-22 The prevalence of BV and candidiasis was found in $38.92 \%$ $(137 / 352)$ and $32.67 \%(115 / 352)$ of women respectively. More than $35 \%$ of symptomatic women had BV in different studies such as Uganda, ${ }^{23}$, Nairobi, Kenya, ${ }^{24}$ Lagos, $^{25}$ Columbia, ${ }^{26}$ Senegal, ${ }^{27}$ and India. ${ }^{18,28-30}$ The differences in the prevalence of $\mathrm{BV}$ in various populations may be due to the different diagnostic criteria for BV, ethnicity, method of contraception etc. ${ }^{20,31-33} \mathrm{~A}$ high prevalence of candidiasis was also observed in women of Senegal, ${ }^{27}$ Punjab, ${ }^{28}$ Tanzania, ${ }^{34}$, Kenya, ${ }^{35}$ Israel, $^{36}$ Delhi, ${ }^{37}$ and Laos. ${ }^{38}$

In this study, BV was more prevalent among women in the age group of $36-45$ years $(47.89 \%)$ followed by $26-35$ years age group (40.21\%) and 18-25 years age groups $(28.74 \%)$ with a statistically significant difference $(\mathrm{p}=0.040)$. From the previous studies there were conflicting results on the association of age with the prevalence of $\mathrm{BV}$ in the reproductive age women. Our result is similar to the finding of Mulu et al., (2015) in Ethiopian and Jones et al., (2007) in Peru. ${ }^{10-11}$ Like BV, the prevalence of candidiasis was found to be significantly high in women with more than 25 years old, which supports the finding of Fang et al., (2007) undertaken in rural area of Shandong, China. ${ }^{12}$ The high prevalence of both BV and candidiasis in 26-45 years age of women may be due to the age being the most reproductively active age groups and high sexual exposure, ${ }^{22}$ pregnancy, weakening of immunity and use of contraceptive. ${ }^{10}$ Further it has been suggested the level of oestrogen reduced after age 40 years which causes an increase in the $\mathrm{pH}$ level enhancing growth of microorganisms responsible for BV. ${ }^{10}$ The history of using contraception was significantly higher in 26-45 years of age women in this study. This is obvious because in the 18-25 age groups, around $20 \%$ of women were unmarried with no history of sexual exposure or contraception used. In a study undertaken in the same state of Odisha, the prevalence of BV and candidiasis was comparable in all the age groups of women. ${ }^{18}$

The high prevalence of BV and candidiasis in 36-45 years age groups in this study can be defined with the association of poor MHM practices as in this age groups, around $60 \%$ of women were used reusable clothes as absorbent materials $(p=0.002), 62 \%$ of women changed their absorbent materials once a day $(\mathrm{p}=0.042), 53.52 \%$ of women changed their absorbent materials outsides the toilet facilities $(p=0.018)$ and $60 \%$ of women reused the absorbent materials $(\mathrm{p}=0.002)$. A poor MHM practices has been significantly associated with the occurrence of BV in a number of studies. The prevalence of BV was found to be higher in women using reusable clothes. ${ }^{18,39,40}$ low frequency of changing absorbent material, ${ }^{18}$ changing of absorbent material outside the toilet facilities, ${ }^{18}$ frequency of washing of genitalia during menstruation, $37,41,42$ douching etc. ${ }^{31}$

It has been observed that the poor MHM practices are associated with socio-demographic features. In this study, woman in the higher age groups had significantly high number of married women, low level of education, housewife (occupation), three or more number of peoples living in house, and living in rural areas (residence) compared to women in the low age groups. The prevalence of BV was found to be high in unmarried women, ${ }^{24}$ whereas high in married women. ${ }^{11}$ Lack of education or low level of education has been found to be significantly associated with occurrence of BV in many studies. ${ }^{12,39,43,44}$ The occurrence of BV was found to be higher in rural women, ${ }^{10}$ however in a study from India, a highest prevalence of women with BV were found in urban slums (38.6\%) followed by rural area $(28.8 \%)$ and then in rural middle class communities (25.4\%). ${ }^{15}$ The prevalence of BV may also vary with the work type of the women.10,40 Similar to BV, the higher prevalence of candidiasis in higher age groups in this study may be due to the lack of education, low economic status and women staying with more than two persons in house etc.

There are certain limitations in this study as we have not investigated others infectious agents like T. vaginalis, Chlamydia, Gonorrhoeae etc. in vaginitis and inclusion of sexual history as variable that may affect the results as many of these women were residing in rural area, belonging to tribal communities and orthodox.

\section{CONCLUSIONS}

From the above discussion it can be concluded that the higher prevalence of BV and candidiasis in higher age groups of women in this study might be due to poor MHM practices and these poor MHM practices are due to their lack of higher education and other low socio-demographic conditions. An increased awareness for MHM practices among these women is important to combat the associated morbidities related to $\mathrm{BV}$ and candidiasis. 


\section{ACKNOWLEDGEMENT}

We acknowledge the support from Head of Department, Department of Obstetrics and Gynaecology and Dean \& Principal of Veer Surendra Sai Institute of Medical Science and Research (VIMSAR), Burla, Odisha.

\section{REFERENCES}

[1] CDC. Bacterial Vaginosis (BV) statistics. www.cdc.gov/std/bv/stats.htm. Accessed on January 10, 2020.

[2] Hillier SL, Holmes KK. Bacterial vaginosis. In: Holmes KK, Sparling PF, Mardh PA, et al. eds. Sexually transmitted diseases. $3^{\text {rd }}$ edn. New York: McGraw-Hill 1999: p. 56386.

[3] Swidsinski A, Mendling W, Loening-Baucke V, et al. Adherent biofilms in bacterial vaginosis. Obstet Gynecol 2005;106(5 Pt 1):1013-23.

[4] Høiby N, Ciofu O, Johansen HK, et al. The clinical impact of bacterial biofilms. Int J Oral Sci 2011;3(2):55-65.

[5] Onderdonk AB, Delaney ML, Fichorova RN. The human microbiome during bacterial vaginosis. Clinical Microbilogy Reviews 2016;29(2):223-38.

[6] "Vaginal Candidiasis". Fungal Diseases. United States: Centers for Disease Control and Prevention. 24th Dec 2019. Accessed on 02 January 2020. https://www.cdc.gov/fungal/diseases/candidiasis/genit al/index.html)

[7] Gonçalves B, Ferreira C, Alves CT, et al. Vulvovaginal candidiasis: epidemiology, microbiology and risk factors. Crit Rev Microbiol 2016;42(6):905-27.

[8] Kenyon C, Colebunders R, Crucitti T. The global epidemiology of bacterial vaginosis: a systematic review. Am J Obstet Gynecol 2013;209(6):505-23.

[9] Achkar JM, Fries BC. Candida infections of the genitourinary tract. Clin Microbiol Rev 2010;23(2):25373.

[10] Mulu W, Yimer M, Zenebe Y, et al. Common causes of vaginal infections and antibiotic susceptibility of aerobic bacterial isolates in women of reproductive age attending at Felegehiwot referral Hospital, Ethiopia: a cross sectional study. BMC Women's Health 2015;15:42.

[11] Jones FR, Miller G, Gadea N, et al. Prevalence of bacterial vaginosis among young women in low-income populations of coastal Peru. Int J STD AIDS 2007;18(3):188-92.

[12] Fang X, Zhou Y, Yang Y, et al. Prevalence and risk factors of trichomoniasis, bacterial vaginosis and candidiasis for married women of child-bearing age in rural Shandong. Jpn J Infect Dis 2007;60(5):257-61.

[13] Patel V, Weiss HA, Mabey D, et al. The burden and determinants of reproductive tract infections in India: a population based study of women in Goa, India. Sex Transm Infect 2006;82(3):243-9.

[14] Uma S, Balakrishnan P, Murugavel KG, et al. Bacterial vaginosis in women of low socioeconomic status living in slum areas in Chennai, India. Sex Health 2006;3(4):2978.
[15] Bhalla P, Chawla R, Garg S, et al. Prevalence of bacterial vaginosis among women in Delhi, India. Indian Journal of Medical Research 2007;125(2):167-72.

[16] Madhivanan P, Krupp $K$, Chandrasekaran V, et al. Prevalence and correlates of bacterial vaginosis among young women of reproductive age in Mysore, India. Indian Journal of Medical Microbiology 2008;26(2):1327.

[17] Das P, Baker KK, Dutta A, et al. Menstrual hygiene practices, WASH access and the risk of urogenital infection in women from Odisha, India. PLoS One 2015;10(6): e0130777.

[18] Torondel B, Sinha S, Mohanty JR, et al. Association between unhygienic menstrual management practices and prevalence of lower reproductive tract infections: a hospital-based cross-sectional study in Odisha, India. BMC Infectious Diseases 2018;18(1):473.

[19] Nugent RP, Krohn MA, Hillier SL. Reliability of diagnosing bacterial vaginosis is improved by a standardized method of gram stain interpretation. J Clin Microbiol 1991;29(2):297-301.

[20] Yen S, Shafer MA, Moncada J, et al. Bacterial vaginosis in sexually experienced and non-sexually experienced young women entering the military. Obstet Gynecol 2003;102(5 Pt 1):927-33.

[21] Garba DJ, Zabaze SS, Tabitha VS, et al. Microbiological diagnosis of bacterial vaginosis in pregnant women in a resource limited setting in north central Nigeria. American Journal of Life Science 2014;2(6):356-60.

[22] Ranjit E, Raghubanshi BR, Maskey S, et al. Prevalence of bacterial vaginosis and its association with risk factors among nonpregnant women: a hospital based study. Article ID 8349601, International Journal of Microbiology 2018;2018:1-9.

[23] Sewankambo N, Gray RH, Wawer MJ, et al. HIV-1 infection associated with abnormal vaginal flora morphology and bacterial vaginosis. Lancet 1997;350(9077):546-50.

[24] Bukusi EA, Cohen CR, Meier AS, et al. Bacterial vaginosis: risk factors among Kenyan women and their male partners. Sex Transm Dis 2006;33(6):361-7.

[25] Onyekonwu CL, Olumide YM, Oresanya FA, et al. Vaginal discharge: aetiological agents and evaluation of syndromic management in Lagos. Niger J Med 2011;20(1):155-62.

[26] Tolosa JE, Rodriguez AE, Angel-Muller E, et al. P2.061 Accuracy of syndromic diagnosis (SD) for vaginal discharge and cervicitis in women of reproductive age in Bogota, Colombia. Sex Transm Infect 2013;89(Suppl 1):A106-A7.

[27] Diadhiou M, Diallo AB, Barry MS, et al. Prevalence and risk factors of lower reproductive tract infections in symptomatic women in Dakar, Senegal. Infectious Diseases: Research and Treatment 2019;12:1178633719851825.

[28] Puri KJ, Madan A, Bajaj K. Incidence of various causes of vaginal discharge among sexually active females in age group 20-40 years. Indian J Dermatol Venereol Leprol 2003;69(2):122-5.

[29] Masand DL, Patel J, Gupta S. Utility of microbiological profile of symptomatic vaginal discharge in rural women 
of reproductive age group. J Clin Diagn Res 2015;9(3):QC04-7.

[30] Kapoor B, Kapoor A, Shah S, et al. Study of prevalence of various disorders and presenting complaints in patients of vaginal discharge. J Evolution Med Dent Sci 2016;5(1):87-91.

[31] Koumans EH, Sternberg M, Bruce C, et al. The prevalence of bacterial vaginosis in the United States, 2001-2004: associations with symptoms, sexual behaviors and reproductive health. Sex Transm Dis 2007;34(11):864-9.

[32] Klatt TE, Cole DC, Eastwood DC, et al. Factors associated with recurrent bacterial vaginosis. J Reprod Med 2010;55(1-2):55-61.

[33] Abdul-Aziz M, Mahdy MAK, Abdul-Ghani R, et al. Bacterial vaginosis, vulvovaginal candidiasis and trichomonal vaginitis among reproductive-aged women seeking primary healthcare in Sana'a city, Yemen. BMC Infectious Diseases 2019;19(1):879.

[34] Mayaud P, Ka-Gina G, Cornelissen J, et al. Validation of a WHO algorithm with risk assessment for the clinical management of vaginal discharge in Mwanza, Tanzania. Sex Transm Infect 1998;(74 Suppl 1):S77-84.

[35] Fonck K, Kidula N, Jaoko W, et al. Validity of the vaginal discharge algorithm among pregnant and non-pregnant women in Nairobi, Kenya. Sex Transm Inf 2000;76(1):33-8.

[36] Dan M, Kaneti N, Levin D, et al. Vaginitis in a gynecologic practice in Israel: causes and risk factors. Isr Med Assoc J 2003;5(9):629-32.

[37] Sharma AK, Ranjan R, Mehta G. Prevalence and determinants of reproductive tract infections among women. J Commun Dis 2004;36(2):93-9.
[38] Sihavong A, Phouthavane T, Lundborg CS, et al. Reproductive tract infections among women attending a gynecology outpatient department in Vientiane, Lao PDR. Sex Transm Dis 2007;34(10):791-5.

[39] Bahram A, Hamid B, Zohre T. Prevalence of bacterial vaginosis and impact of genital hygiene practices in nonpregnant women in Zanjan, Iran. Oman Med J 2009;24(4):288-93.

[40] Baisley K, Changalucha J, Weiss HA, et al. Bacterial vaginosis in female facility workers in north-western Tanzania: prevalence and risk factors. Sex Transm Infect 2009;85(5):370-5.

[41] Vaca M, Guadalupe I, Erazo S, et al. High prevalence of bacterial vaginosis in adolescent girls in a tropical area of Ecuador. BJOG 2010;117(2):225-8.

[42] Bitew A, Abebaw Y, Bekele D, et al. Prevalence of bacterial vaginosis and associated risk factors among women complaining of genital tract infection. Article ID 4919404, International Journal of Microbiology 2017;2017:1-8.

[43] Allsworth JE, Peipert JF. Prevalence of bacterial vaginosis: 2001-2004 National Health and Nutrition Examination Survey Data. Obstet Gynecol 2007;109(1):114-20.

[44] Lan PT, Lundborg CS, Phuc HD, et al. Reproductive tract infections including sexually transmitted infections: a population-based study of women of reproductive age in a rural district of Vietnam. Sex Transm Infect 2008;84(2):126-32. 